\title{
ARTE, CIDADE E TEMPORARIEDADE: O IMPACTO DA ARTE URBANA EM JOÃO PESSOA-PB
}

\author{
ARTE, CIUDAD Y TEMPORARIDAD: EL IMPACTO DEL ARTE URBANO EM JOÃO PESSOA-PB
}

ART, CITY AND TEMPORARITY: THE IMPACT OF URBAN ART IN JOÃO PESSOA-PB

\section{DIMENSTEIN, MARCELA}

Mestre PPGAU/UFPB, docente Centro Universitário de João Pessoa, doutoranda PPGAU/UFRN, mmarcelad@gmail.com

\section{MELO, JULIÊ CAROLINE DOS SANTOS}

Bacharela, Centro Universitário de João Pessoa, juliecsmelo@outlook.com

\section{RESUMO}

As cidades contemporâneas estão presenciando o aparecimento de espaços homogeneizados, sem identidade e que proporcionam efemeridade nas relações sociais - que transformam lugares que possuem uma vocação de permanência em locais meramente de passagem. Entretanto, ainda é possível encontrar formas de resistência que utilizam a obra de arte como ferramenta de aproximação entre indivíduo e o urbano. Este artigo traz resultados de um trabalho de conclusão de curso, finalizado em 2017, sobre o impacto da arte urbana temporária em dois bairros da capital paraibana, a fim de investigar os efeitos dela sobre o espaço, seus usos e usuários, expandindo as discussões sobre as relações entre arte e cidade.

PALAVRAS-CHAVE: intervenção artística temporária; arte contemporânea; arte e cidade; arte urbana.

\section{RESUMEN}

Las ciudades contemporáneas están presenciando la aparición de espacios homogeneizados, sin identidad y que proporcionan efemeridad en las relaciones sociales - que transforman lugares que poseen una vocación de permanencia en espacios meramente de paso. Sin embargo, todavía es posible encontrar formas de resistencia que utilizan la obra de arte como herramienta de acercamiento entre individuo y lo urbano. Este artículo trae resultados de un trabajo de conclusión de curso, finalizado en 2017, sobre el impacto del arte urbano temporal en dos barrios de la capital paraibana, a fin de investigar los efectos de ella sobre el espacio, sus usos y usuarios, ampliando las discusiones sobre las relaciones entre arte y ciudad.

PALABRAS CLAVES: intervención artística temporal; arte contemporaneo; arte y ciudad; arte urbano.

\section{ABSTRACT}

Contemporaty cities are witnessing the emergence of homogenized spaces, which lack identity and provide ephemerality in social relations - transforming places which have a natural tendence to promote permanence in merely passing-through places. However, it is still possible to find resistance forms that use the work of art as a form of approximation between individual and urban. This article presents the results of a work completed in 2017 on the impact of temporary urban art in two districts of the capital of Paraiba, in order to investigate the effects of it on space, its uses and users, expanding the discussions on the relationship between art and the city.

KEYWORDS: temporary artistic intervention; contemporary art; art and city; urban art. 


\section{INTRODUÇÃO}

Este artigo apresenta os resultados de um Trabalho de Conclusão de Curso (TCC) finalizado em 2017 no Centro Universitário de João Pessoa, o qual abordou o impacto da arte urbana temporária na cidade contemporânea (MELO, 2017). Este tema permite diversas perspectivas, entretanto, o estudo embarcou uma visão arquitetônica e urbanística sobre a arte, tendo em vista que este campo abrange não somente espaços edificados, mas também a percepção e apropriação do indivíduo sobre a cidade. Recentemente, a ligação entre arte e cidade vem sendo trabalhada por autores como Vera Pallamin (2000, 2002), Zalinda Cartaxo (2007, 2009), Fabiana Britto e Paola Jacques (2009), e Adriana Fontes (2011). Estas últimas apontam que a cidade contemporânea vem se mostrando cada vez mais complexa, e que pensamentos generalistas têm dado lugar aos estudos urbanos transdisciplinares.

Ao longo dos períodos históricos, os elementos arquitetônicos se mostraram um modo de traduzir a sociedade de sua época, assim como outras produções artísticas. Por isto, os estudos de Arquitetura e Urbanismo geralmente andam em conjunto com os estudos de Artes. Por conseguinte, considerando que as demais formas de arte não necessariamente tratam dos efeitos que causam da mesma maneira que a arquitetura os trata, a arte urbana se apresenta como importante meio de transmitir o quadro da sociedade atual, sem censuras e receios.

Para melhor compreensão do papel da arte urbana na contemporaneidade é necessário entender o cenário recente de produção e apropriação da cidade, sobretudo em razão do mercado, da política e da cultura estarem cada vez mais conectados mundialmente. Nesse campo, Jean-François Lyotard (1979) aponta que ocorreu um colapso de grandes narrativas no final do século XX: as visões utópicas de mundo, as tradicionais religiões e formas de pensar a sociedade se dissiparam devido aos avanços científicos e tecnológicos do período pós-guerra, reduzindo as certezas ilusórias e deixando espaço para dúvidas (NASCIMENTO, 2011). Associadas a isto, a ascensão do capitalismo e sua sede por lucro a curto prazo resultaram em indivíduos motivados pelo presente, tendo em vista que as certezas do futuro não existiam mais.

Por conseguinte, o foco no presente fez com que a efemeridade fosse a principal característica da sociedade pós-moderna, evidenciando maior valor ao rápido, superficial e momentâneo (BAUMAN, 2001). Estamos diante de uma realidade onde o curto prazo, a falta de compromisso mútuo e a superficialidade são intrínsecos às relações sociais. Assim também, Guy Debord (2003), em seus escritos de 1960 sobre comunidades geridas pelas circunstâncias modernas de produção, conceituou a sociedade do espetáculo como uma forma de sociedade superficial e de consumo passivo. Nela, as relações sociais, que antes evoluíram do ser para o ter, agora evoluíram do ter para o parecer.

Seguindo essa linha de pensamento, Jacques (2005) aponta que as cidades atuais estão cada vez mais parecidas umas com as outras. A autora explica que isto resulta da disseminação de um modelo urbano homogeneizante ao redor do mundo, em favor de grandes empresas e financiadores multinacionais. Assim, é possível encontrar, principalmente em cidades de médio e grande porte, paisagens urbanas padronizadas, o surgimento de espaços de grande escala, o fomento do uso do automóvel, a disseminação de uma cultura individualista, especulação imobiliária, aumento das estatísticas de violência e destruição ambiental (DIMENSTEIN, 2014). Em decorrência disto, estas mesmas cidades se tornaram reféns da negligência à escala humana, da perda do significado do espaço urbano enquanto lugar de encontros e experiências, e do surgimento desenfreado de grandes empreendimentos.

Em seus estudos sobre as cidades contemporâneas Fontes (2011) aponta como os teóricos inclinam seus pensamentos ao pior lado da situação atual: a efemeridade enquanto geradora de hostilidade. Entretanto, ela afirma ser possível extrair, dessa condição efêmera, um sentido de válvula de escape, geradora de libertação para os citadinos. Assim, segundo Jan Gehl (2009), a presença de atividades pequenas, pontuais e espontâneas nos espaços públicos pode gerar voz em meio aos espaços escassos de identidade. Dialogando com isto, Pallamin (2000) discursa sobre como o estudo da arte urbana permite a compreensão dos modos de produção da cultura urbana, que envolvem não só relações dentro de determinados grupos sociais produtores da arte, mas, também, a relação destes grupos com os habitantes receptores das obras artísticas, e a relação dos produtores e receptores com a cidade.

Partindo desse quadro geral, na pesquisa apresentada nesse artigo entende-se que as intervenções artísticas temporárias se inserem como um respiro à forma de viver na contemporaneidade, uma vez que elas possibilitam, e até estimulam, que os habitantes interajam e reflitam sobre algum tema. Serão aqui expostos os resultados de duas intervenções urbanas temporárias propostas em 2017 como produto de TCC em Arquitetura e Urbanismo. Os locais de estudo foram dois bairros da cidade de João Pessoa, Paraíba: Jardim Cidade Universitária e Tambaú. 
A elaboração das intervenções baseou-se nas potencialidades apresentadas pelos bairros, de acordo com os tipos de arte urbana preexistentes, os quais foram detectados durante levantamento categórico das intervenções artísticas temporárias. Tal estudo aconteceu entre março e agosto de 2017, com a realização de 12 visitas de campo, nas quais foi possível identificar como manifestações artísticas pré-existentes: grafite, performance, lambe-lambe, grafite apagado ${ }^{1}$ e escultura no Jardim Cidade Universitária; grafite, performance e grafite apagado em Tambaú.

Durante o processo de intervenção e depois dele foram realizados: (i) observação sistemática dos locais (do tipo não-participante); (ii) registro fotográfico das intervenções e do público; (iii) entrevistas semiestruturadas (envolvendo a opinião do público sobre a intervenção proposta, obras de arte em geral e a relação delas com a cidade); (iv) criação de uma hashtag ${ }^{2}$ nas redes sociais (o que possibilitou outra forma de ver a interação do público com a arte). Estes métodos e ferramentas de pesquisa foram utilizados para investigar de que maneira(s) a presença de arte temporária influencia a dinâmica de uso/ocupação daqueles espaços urbanos e qual o impacto disso nos citadinos. O processo metodológico e os resultados encontrados serão apresentados nos tópicos seguintes.

Uma das principais bases da atividade foi o entendimento do conceito de Robert Temel ${ }^{3}$ (apud FONTES, 2011), segundo o qual o temporário está entre o efêmero e o provisório. O efêmero diz respeito a algo que, após seu curto ciclo de vida, não pode ser estendido. Por sua vez, o provisório, pode estender sua breve duração por algum tempo a mais, enquanto algo de melhor qualidade não é providenciado para substituição. Por fim, o temporário inicia com a vida curta do efêmero e pode ser estendido como o provisório, embora sem ser substituto de algo.

Assim, também, a palavra intervenção foi escolhida no sentido de expressão e interferência. Para alguns autores, interferência e intervenção têm o mesmo significado e dizem respeito a toda manifestação artística feita na cidade (IMBROISI; MARTINS, 1998). A explicação arquitetônica e urbanística de Fontes (2011) sobre interferência é de que se trata de uma interrupção na rotina do espaço urbano.

Desta forma, as intervenções aqui analisadas se inserem no conceito de arte contemporânea e se mostram como rupturas temporárias no cotidiano do espaço urbano. Através da arte, tais rupturas expressam a relação do citadino com as cidades e as pessoas.

\section{SOBRE ARTE E ARQUITETURA}

Em seu livro A História da Arte (2000, p. 15), Ernst Gombrich afirma que "nada existe realmente a que se possa dar o nome de Arte. Existem somente artistas." Isto se dá pelos diferentes significados que cada sociedade emprega, fazendo com que as limitações e regras sobre a arte não resistam por muito tempo. Ao longo dos períodos históricos, diferentes definições de arte foram adotadas de acordo com os distintos contextos sociais.

Nesse sentido, Margaret Imbroisi e Simone Martins (1998) explicitam que a arte pode assumir três grandes significados: ofício, conhecimento e expressão. O primeiro significado foi concebido baseado no aspecto da habilidade executiva e manual; no segundo, o objeto criado permanece em segundo plano, assim prevalecendo seu significado enquanto visão da realidade; por último, o sentido de expressão, que provém especialmente do Romantismo, une a forma do objeto aos sentimentos que impulsionaram sua criação.

Por sua vez, de acordo com Gombrich (2000, p. 612) "a arte é considerada a principal expressão de cada época", afirmativa que corrobora com o pensamento das autoras anteriores ao ressaltarem que:

A arte registra ideias e as ideologias de culturas e etnias, sendo assim, ela se torna fundamental para a compreensão da história da humanidade e do mundo. Formas artísticas podem extrapolar a realidade, exagerar coisas aceitas ou simplesmente criar novas formas de se observar a realidade (IMBROISI, MARTINS, 1998, s/p).

A arte nem sempre esteve ligada ao sentido de expressão sentimental, tendo em vista que este significado está efetivamente conectado ao século XIX. Entretanto, por todos os períodos históricos e pré-históricos onde houve manifestações artísticas de qualquer natureza, a arte esteve diretamente relacionada com a expressão do contexto social das comunidades (GOMBRICH, 2000).

A literatura (DEBORD, 2003; GOMBRICH, 2000; ZEVI, 2009) faz toda uma discussão sobre a relação entre arte e arquitetura, destacando pontos convergentes e divergentes entre ambas. Bruno Zevi, em seu livro Saber Ver Arquitetura, afirma que o erro de tratar a Arquitetura como as outras formas de arte:

[..] consiste no fato de os edifícios serem apreciados como se fossem esculturas e pinturas, ou seja, externa e superficialmente, como simples fenômenos plásticos. [...] Dessa forma, 
se esquecem de considerar o que é específico da Arquitetura e, portanto, diferente da escultura e da pintura, ou seja, no fundo, o que vale na Arquitetura como tal (ZEVI, 2009, p. 5).

De fato, embora por um lado a área de Arquitetura e Urbanismo seja diferente das demais manifestações artísticas no que diz respeito ao modo de tratar os efeitos que causam sobre aqueles que dela usufruem, por outro lado, assim como as outras artes, ela também representa a expressão do contexto social de determinada época, o que faz com que os estudos artísticos frequentemente dialoguem com os arquitetônicos e urbanísticos na compreensão da sociedade. Sobre isto, Pallamin afirma:

A arte urbana é uma prática social. Suas obras permitem a apreensão de relações e modos diferenciais de apropriação do espaço urbano, envolvendo em seus propósitos estéticos o trato com significados sociais que as rodeiam, seus modos de tematização cultural e política (PALLAMIN, 2000, p. 23-24).

O desejo de aproximação da arte com a realidade levou vários artistas a preferirem o cotidiano das cidades às galerias. Assim, segundo Cartaxo (2009), "o espaço asséptico da galeria 'cubo branco', puro e descontaminado, foi substituído pelo espaço impuro e contaminado da vida real" (p. 3). Em contrapartida, Nelson Peixoto (2012) explica que, ao longo dos anos, essa situação mudou: a cidade deixou de ser apenas um novo tipo de galeria e passou a ter valor intrínseco às intervenções artísticas.

Nesse contexto, as intervenções artísticas temporárias surgem como expressão do descontentamento com o quadro atual das cidades (FERREIRA; KOPANAKIS, 2005); em meio a espaços frios, sem identidade e reféns da superficialidade, as propostas surgem como válvulas de escape e esperança de transformações. Assim, elas também se mostram como mecanismo de propagação de ideias e ideais a qualquer tipo de público, inclusive àqueles que não têm acesso à informação.

Pallamin (2002) afirma que estas manifestações despertam visibilidade, apontam ausências de poder público, criam resistências à exclusão e geram convivências entre citadinos. Além disto, o autor levanta 0 questionamento sobre como, por quem e para quem os espaços urbanos são criados, bem como quem são as vozes dominantes e quem exerce a produção, participação e usufruto da cultura. Similarmente, Cartaxo $(2009$, p. 6) afirma que "por intermédio da arte pública, a cidade como locus funciona como meio de reflexão do ser no mundo contemporâneo". As manifestações despertam alteridade em meio a cidades reféns do processo de espetacularização urbana, saturadas de espaços coletivos sem conexão social.

Nesta mesma linha de pensamento, Fontes (2011) conceitua amabilidade como o atributo que dá significado ao espaço escasso de identidade à medida que estimula vínculos sociais e conexões das pessoas com o espaço. A autora defende que intervenções artísticas temporárias despertam a amabilidade de um lugar e deixam marcas permanentes nele.

Ao mesmo tempo em que a intervenção interage com as pessoas, faz também com que estas interajam entre si, aproximando-as, vitalizando os espaços e dando origem a um novo ciclo que se auto alimenta, uma vez que a amabilidade pode permitir novas intervenções, que vão gerar espaços cada vez mais amáveis, e assim sucessivamente (FONTES, 2011, p. 15).

Portanto, as intervenções artísticas temporárias se inserem na cidade como prática crítica, reflexo do contexto social, permitindo ações que enaltecem a voz da população. Elas possibilitam que os citadinos usufruam dos espaços urbanos margeando os usos determinados pelos planejadores e pelo poder público. Sua temporariedade destaca não só a proposta do artista, mas também a censura e negligência do poder público.

\section{INTERVENÇÕES EM DOIS BAIRROS DE JOÃO PESSOA}

É notável a presença de intervenções artísticas em João Pessoa, cidade em que aconteceu este estudo. Ao primeiro olhar cabe a limitada ideia da existência de arte urbana apenas na forma de grafite e pichação. Entretanto, à medida que se compreende a abrangência dos conceitos de arte contemporânea, é possível a identificação de outras modalidades artísticas.

Para a realização das duas intervenções urbanas temporárias, partiu-se de um estudo dos dois bairros: o Jardim Cidade Universitária e o Tambaú - localizados em escala nacional, estadual e municipal na Figura 1. O Jardim Cidade Universitária está situado na zona sul em uma área de atual expansão da capital; por ser um bairro de baixa diversidade de usos (85\% residencial), durante as observações de campo foram identificadas poucas trocas de experiências sociais no espaço público. Por sua vez, Tambaú é um bairro consolidado na década de 1940 e situado na zona leste do município, e se apresentou com mais vivacidade e com grande diversidade de usos. 
Figura 1: Localização do estado, município e bairros

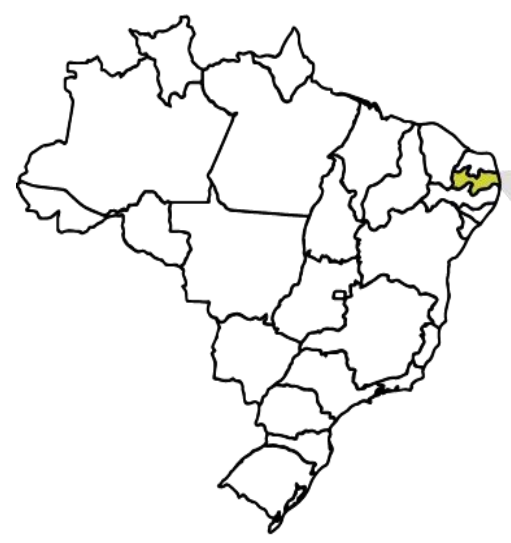

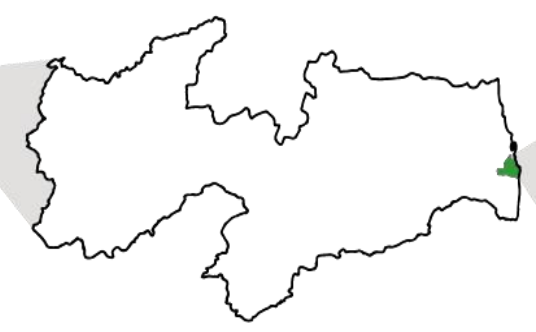

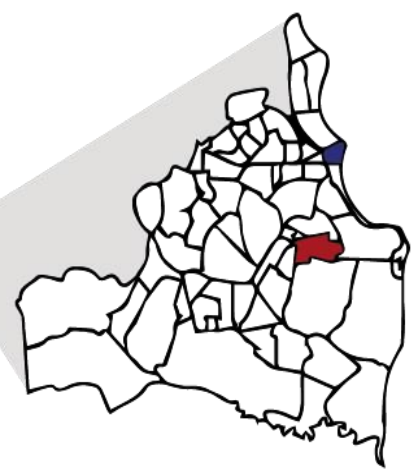

Legenda:
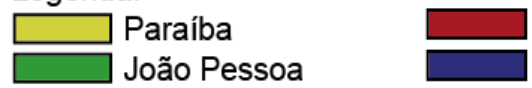

Jd. Cidade Universitária

Tambaú

Fonte: elaborado pelas autoras, 2018.

A pesquisa observacional, voltada à identificação e categorização das intervenções artísticas temporárias, foi realizada por meio de 12 visitas aos bairros estudados. Associados a isto foram feitos registros fotográficos e caracterização tanto das intervenções artísticas temporárias já existentes, quanto do espaço em que elas se inseriam. As visitas ocorreram entre os dias 18 de março e 26 de agosto de 2017, variando entre horários de turno matutino, vespertino e noturno, em dias úteis e fins de semana.

A análise da arte temporária encontrada no estudo dos bairros mostrou que em Tambaú existiam grafites, grafites apagados e performances (Figura 2). Enquanto isto, no Jardim Cidade Universitária foram vistos grafites, grafites apagados, esculturas, lambe-lambe e performances (Figura 3) - nesta pesquisa 0 termo "grafite" engloba ambos grafite e pichação ${ }^{4}$, o que se dá pelo entendimento de que a pichação e o grafite brasileiros têm o mesmo objetivo de expressão e visibilidade (NOGUEIRA, 2009), apenas divergindo no que se refere a sua legalidade ${ }^{5}$.

Figura 2: Artes encontradas em Tambaú, respectivamente: performance, grafite, grafite apagado.

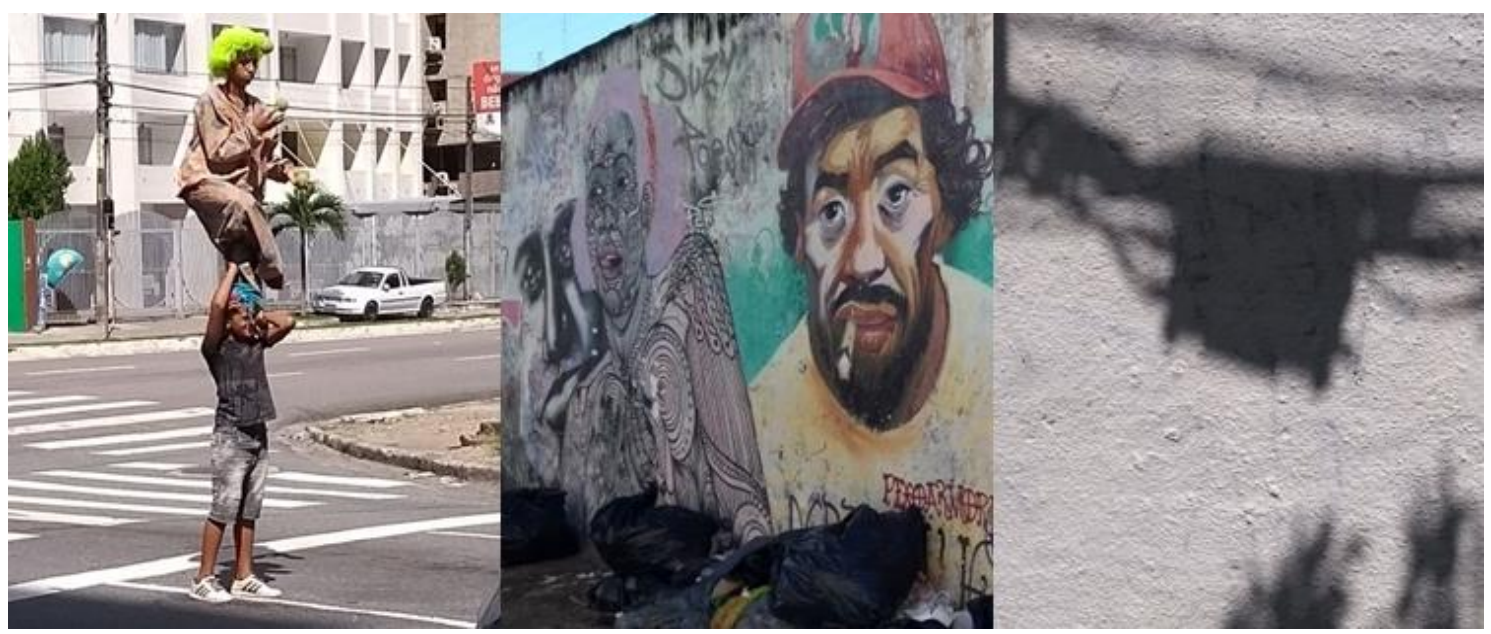

Fonte: elaborado pelas autoras, 2017. 
Figura 3: Artes encontradas no Jardim Cidade Universitária: performance, grafite, escultura, grafite apagado, lambe-lambe.

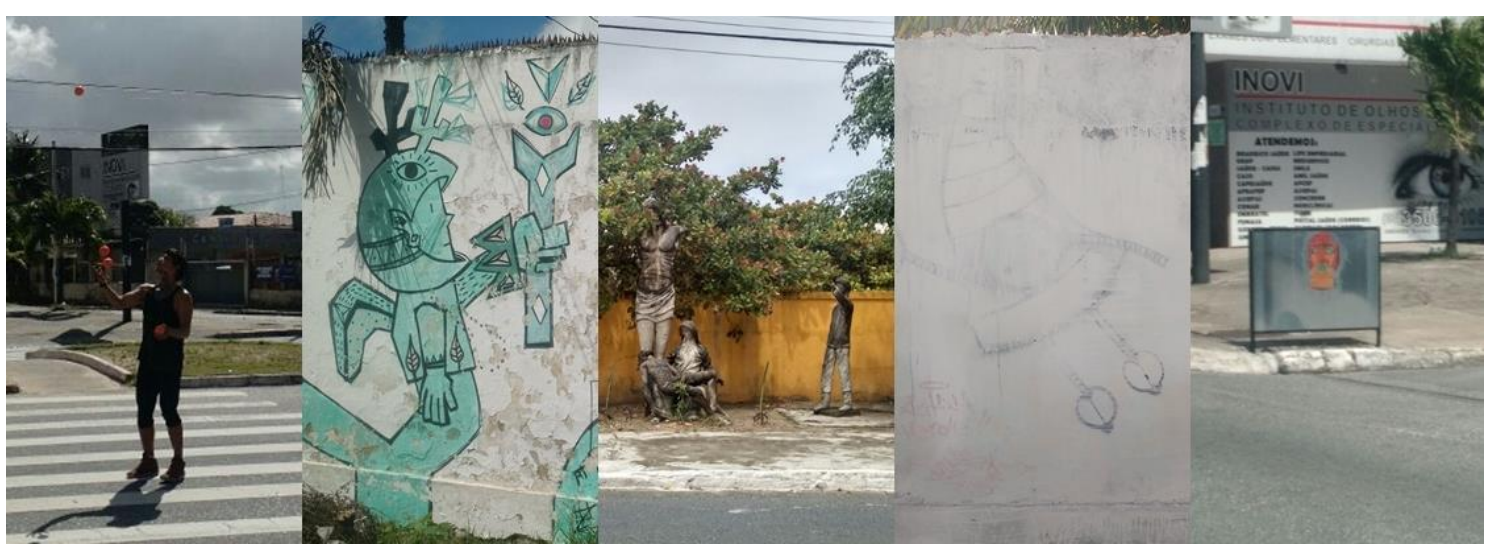

Fonte: elaborado pelas autoras, 2017.

\section{Realização das intervenções artísticas temporárias}

Após o estudo observacional e de catalogação dos bairros, a etapa seguinte consistiu em propor intervenções que dialogassem com a potencialidade dos bairros, baseado nas artes previamente encontradas. Levando em consideração que a arte temporária pode sofrer alterações de terceiros, foram realizadas posteriores visitas para o registro dessas possíveis mudanças.

Além disto, algumas entrevistas foram feitas com os receptores das intervenções propostas. Segundo Tatiana Gerhardt e Denise Silveira (2009), a entrevista semiestruturada é toda aquela que segue um roteiro prévio organizado pelo pesquisador, porém permite que o entrevistado tenha liberdade de falar livremente. Por se tratar de um estudo sobre questões subjetivas, este método foi escolhido tendo em mente que a adaptação da entrevista de acordo com o ambiente e o entrevistado poderia gerar resultados voltados à vertente qualitativa escolhida.

A partir dos resultados encontrados nas observações de campo, foi possível notar que o Jardim Cidade Universitária apresentou uma maior potencialidade para intervenções que não necessitam de interação direta. Enquanto isto, as artes encontradas em Tambaú exploraram com maior força a performance e o contato direto entre artista e receptor da arte. Desta forma, as intervenções propostas foram de acordo com estas constatações: em Tambaú foi feita uma performance, e no Jardim Cidade Universitária foram colocados três tipos de lambe-lambe.

No que diz respeito às interações com as artes propostas, enquanto as relações diretas ocorreram quando a autora e os receptores da arte estiveram frente a frente, auxiliadas pela entrevista semiestruturada, as comunicações indiretas envolveram a intermediação de outras ferramentas, como a documentação das alterações feitas e o acompanhamento de uma hashtag criada. Assim, ao passo que a interação direta envolve manifestação explícita de opinião sobre a arte aplicada, a interação indireta necessita de interpretação.

\section{- Jampa Tem Cor}

São frequentes os exemplos de manifestações artísticas que utilizam poesias para quebrar a rotina das cidades com algo que desperte sensações, e nesta pesquisa o intuito dos lambe-lambes foi exatamente este. A intervenção feita no Jardim Cidade Universitária se intitulou "Jampa Tem Cor". Objetivou-se, com ela, a reflexão pessoal e sobre a cidade, além de permitir interação com a intervenção.

Foram feitos três modelos de lambe-lambes, com várias séries dentre eles:

1) O primeiro consiste em caça-palavras baseados em letras de música nacionais famosas. Eles foram dispostos em paradas de ônibus, desta forma o receptor da intervenção reutilizaria seu tempo de espera.

2) O segundo modelo consistiu em o receptor escrever o que ele gostaria que aquele local fosse; foram colocados em muros de lotes vazios e em edificações sem uso.

3) Por fim, o terceiro modelo diz respeito a versos de músicas nacionais famosas, com objetivo de despertar algum sentimento no espectador, e foram dispostos em locais que proporcionassem grande visibilidade.

A Figura 4 apresenta exemplos do que foi proposto.

Figura 4: Lambe-lambes aplicados, em ordem respectiva à explicação de cada um. 


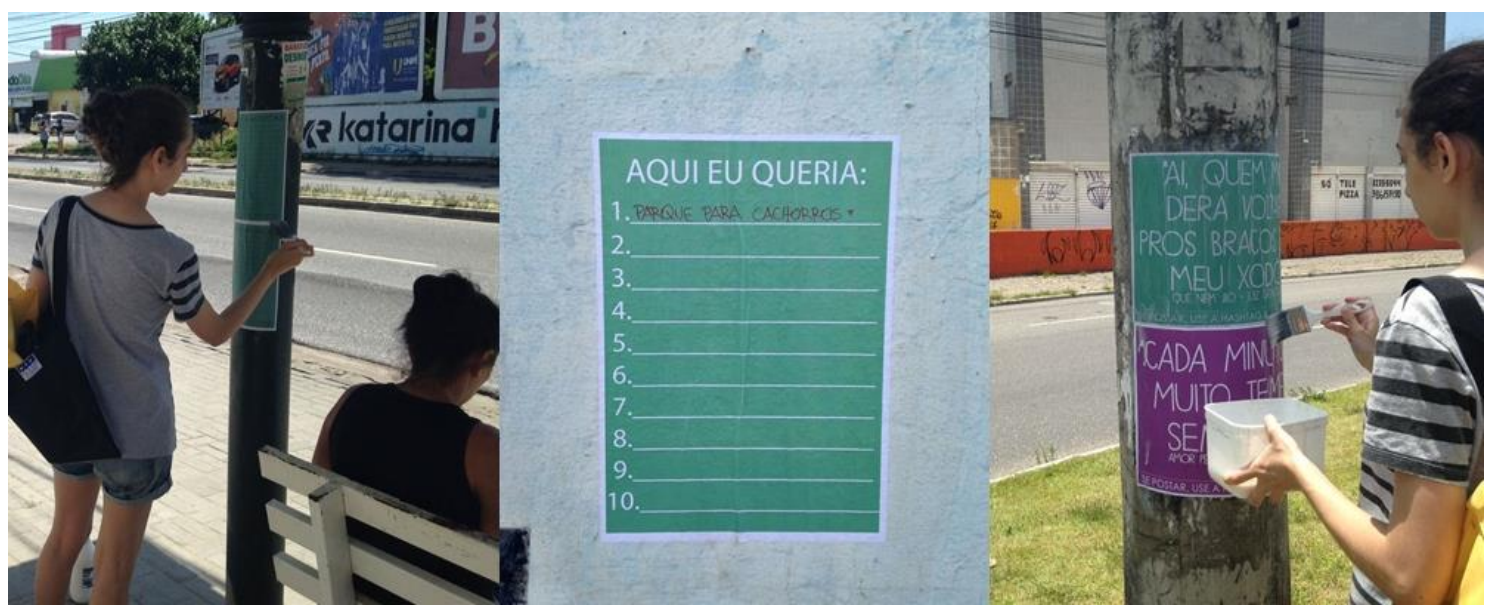

Fonte: elaborado pelas autoras, 2017.

De forma geral, durante a atividade percebeu-se que muitas pessoas observavam o que estava acontecendo, com olhares curiosos e de desaprovação, enquanto outras pessoas ignoravam ou desviavam o olhar quando a autora os percebia.

A fixação dos lambe-lambes de caça-palavras recebeu maior atenção dos transeuntes. Enquanto uma das autoras e a acompanhante debatiam sobre o melhor espaço na parada de ônibus para a colagem, uma senhora sugeriu colar por cima de um anúncio que já estava ali há muito tempo e encorajou o ato, mesmo sem saber do que se tratavam os lambe-lambes. Logo mais, após a colagem, uma jovem quis saber como funcionava a resolução do caça-palavras e o observou por alguns instantes.

A fim de documentar o contato da população com os lambe-lambes, foi criada a hashtag \#jampatemcor, para os receptores publicarem fotos nas redes sociais e, desta forma, viabilizar sua interação com a intervenção. Para impulsionar o alcance da ferramenta e estimular a população a utilizá-la, seis fotos foram adicionadas na rede social Facebook e no aplicativo de fotos Instagram. Durante o período de análise, duas publicações foram percebidas como interação da população com as artes. Contudo, após a finalização do estudo, mais três fotos foram publicadas utilizando a hashtag da pesquisa.

O segundo modelo proposto foi colado com uma frase inicial, levando-se também em consideração que talvez alguém pudesse não entender o objetivo da proposta. Apenas uma interação deste tipo foi identificada, entretanto, o registro dela foi feito após dias de chuva constantes, o que interferiu na leitura da frase escrita.

Por fim, assim como as intervenções encontradas no Jardim Cidade Universitária, os lambe-lambes propostos também foram modificados. Houve pintura sobre a arte aplicada - igualando-a com a superfície onde se encontra, substituição dela por outro objeto, e abertura de rasgos (Figura 5).

Figura 5: Lambe-lambe rasgado e lambe-lambe coberto por tinta, com área destacada em vermelho.

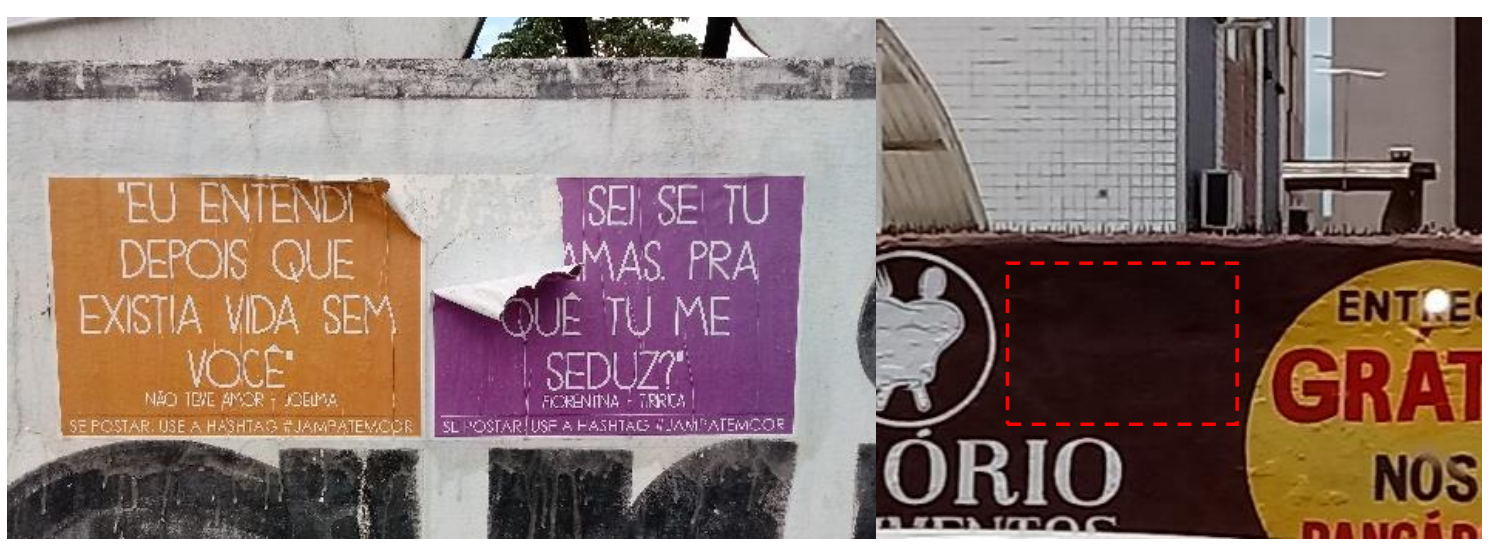

Fonte: autoria de Alana Maluf Vilela, 2017, editado pelas autoras.

\section{- Todo Lugar É Lugar Para Qualquer Coisa}


É muito comum vermos espaços na cidade que reinventam sentidos e usos previamente estabelecidos. Eloísa Mendes explica que "a própria cidade se faz matéria de criação não apenas do artista, mas de todos que reinventam os sentidos do espaço urbano através da experiência estética compartilhada” (2012, p. 6). Isto corrobora com a afirmação do artista Felipe Morozini, de que "qualquer espaço é lugar para qualquer coisa" (informação verbal) ${ }^{6}$, a qual inspirou o título da intervenção feita em Tambaú: Todo Lugar É Lugar Para Qualquer Coisa.

Desta forma, elaborou-se uma performance que foi de encontro com estas constatações, correspondendo a uma atividade fora de seu contexto natural, com intuito de levantar a reflexão sobre apropriação de espaços. A atividade, inserida no Complexo Alimentar Varandas de Tambaú, consistiu em um grupo de pessoas dentro de uma piscina vazia (Figuras 6 e 7), e incluiu alguns objetos que remetem à praia.

Figura 6: Apresentação da performance no bairro de Tambaú - JP.

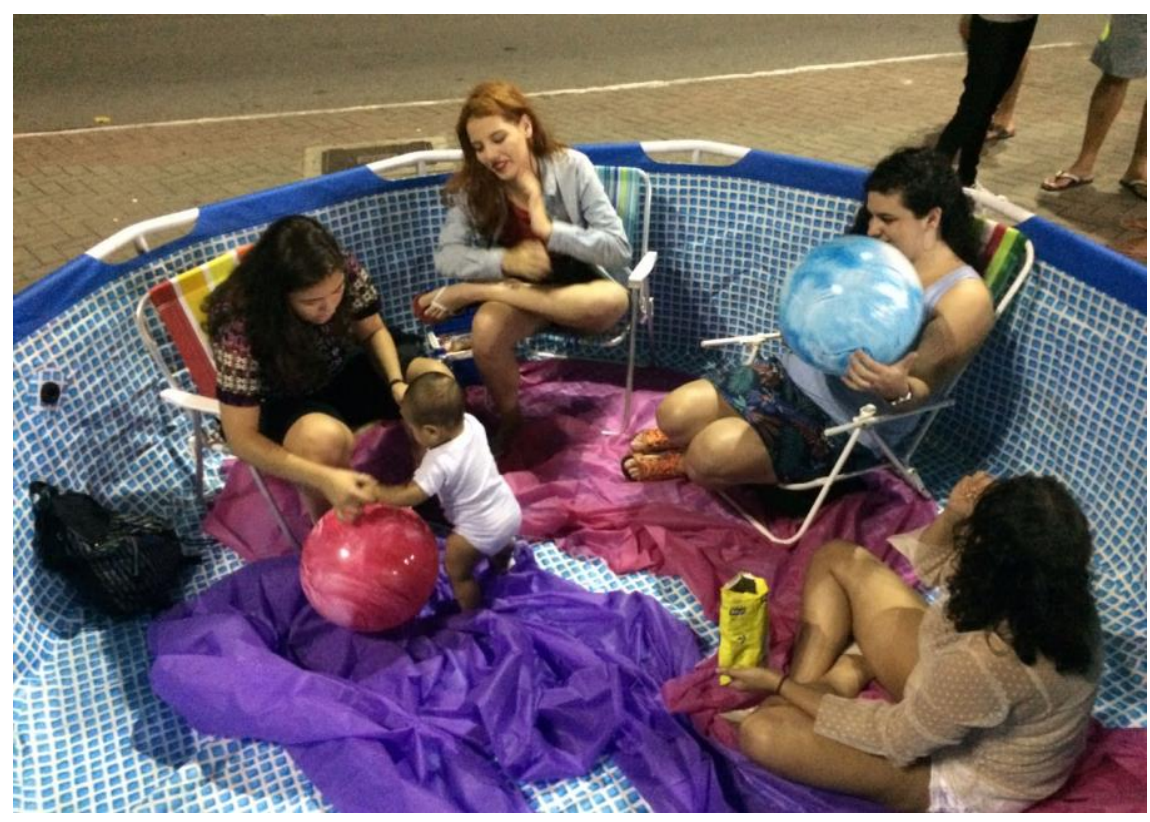

Fonte: autoria de Cristiane Limeira de Farias, 2017.

Figura 7: Apresentação da performance no bairro de Tambaú - JP.

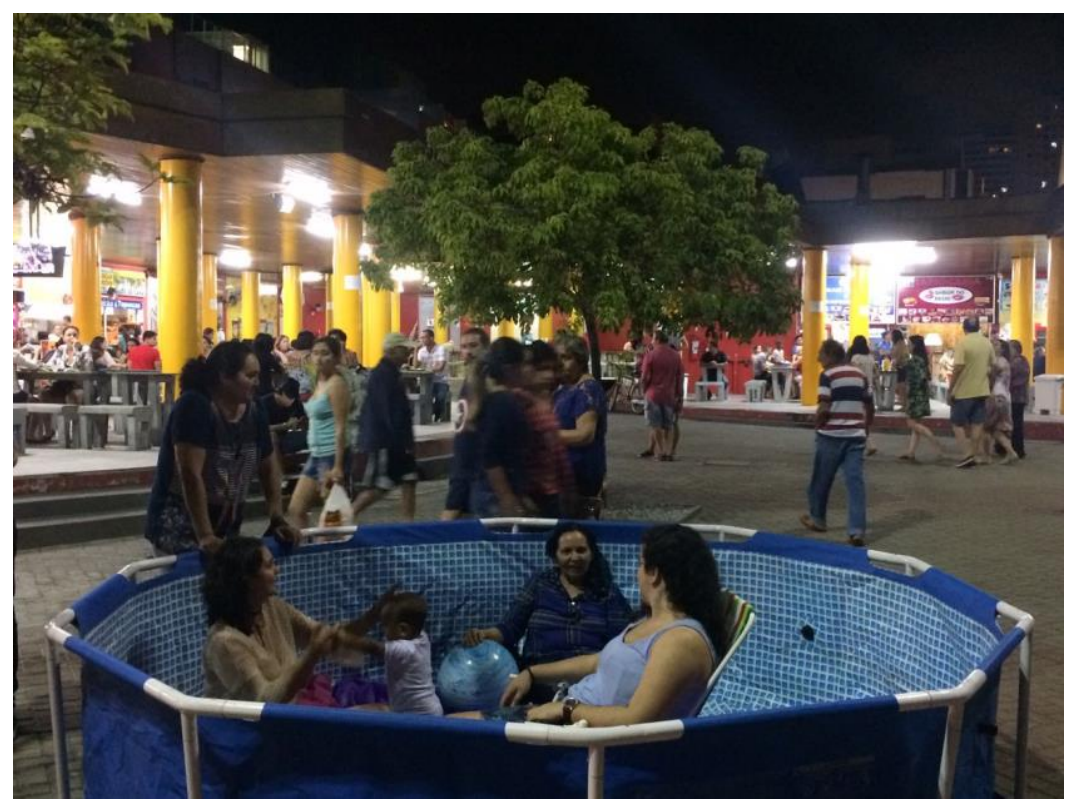

Fonte: autoria de Cristiane Limeira de Farias, 2017. 
De forma geral, muitas pessoas observavam com curiosidade o que estava acontecendo, comentando detalhes com seus acompanhantes, enquanto outras pessoas simplesmente ignoravam. Depois de algum tempo, funcionários da Secretaria de Desenvolvimento Urbano (SEDURB) apareceram para averiguar o que estava acontecendo, sem abordar os participantes da arte. Um vendedor ambulante afirmou que não havia nada errado e disse-Ihes que a piscina fazia parte de uma pesquisa acadêmica, como ele tinha buscado saber previamente com integrantes da intervenção. Após alguns minutos de observação os funcionários da SEDURB foram embora.

Algumas pessoas se aproximaram para verificar do que se tratava, e isto resultou em 19 entrevistas semiestruturadas (dentre estas, 3 feitas com participantes da performance). A maior parte dos entrevistados era de adultos, mulheres, estudantes e residentes de João Pessoa. Dentre os participantes a maioria disse gostar de arte, enquanto uma parcela pequena disse não entender sobre o assunto; apenas uma minoria informou não produzir nenhuma manifestação artística. Além disso, a respeito de arte urbana propriamente dita, a maior parte dos entrevistados concordou que ela deve estar na cidade e não somente em galerias e museus. Dentre os entrevistados, mais da metade afirmou gostar da intervenção, enquanto uma pequena parcela disse não gostar ou achar muito estranho, e a minoria não demonstrou opinião.

Quando questionados sobre o que achavam que era o objetivo da intervenção, as respostas envolveram: um ato de publicidade, um tipo de berçário ou espaço reservado para crianças, e uma prova de resistência para saber quem aguentava ficar mais tempo dentro da piscina. Além disto, os participantes também acharam se tratar de algo para chamar atenção sem especificar mais, e apenas duas pessoas afirmaram que se tratava de algo relacionado à arte.

Uma pequena parcela respondeu que a performance em questão teve relação com o ambiente inserido, e também apenas a minoria demonstrou a opinião de que a arte não deveria ser removida. Por fim, ao serem questionados se aquela intervenção poderia ser considerada 'sinônimo de arte', menos da metade concordou (resposta afirmativa), enquanto uma pequena parcela negou e a minoria não respondeu. Dentre os que emitiram resposta afirmativa, uma parcela significativa alegou que, mesmo entendendo ser arte, ainda considerava a manifestação muito estranha.

As Figuras 8 e 9 (resultado gráfico das respostas obtidas) ilustram o que foi percebido durante as conversas. Elas apresentam as opiniões dos entrevistados e a hierarquia no tamanho das letras (palavras) condiz com a quantidade de respostas encontradas (quanto maior a letra mais menções).

Figura 8: Resultado gráfico das entrevistas semiestruturadas.

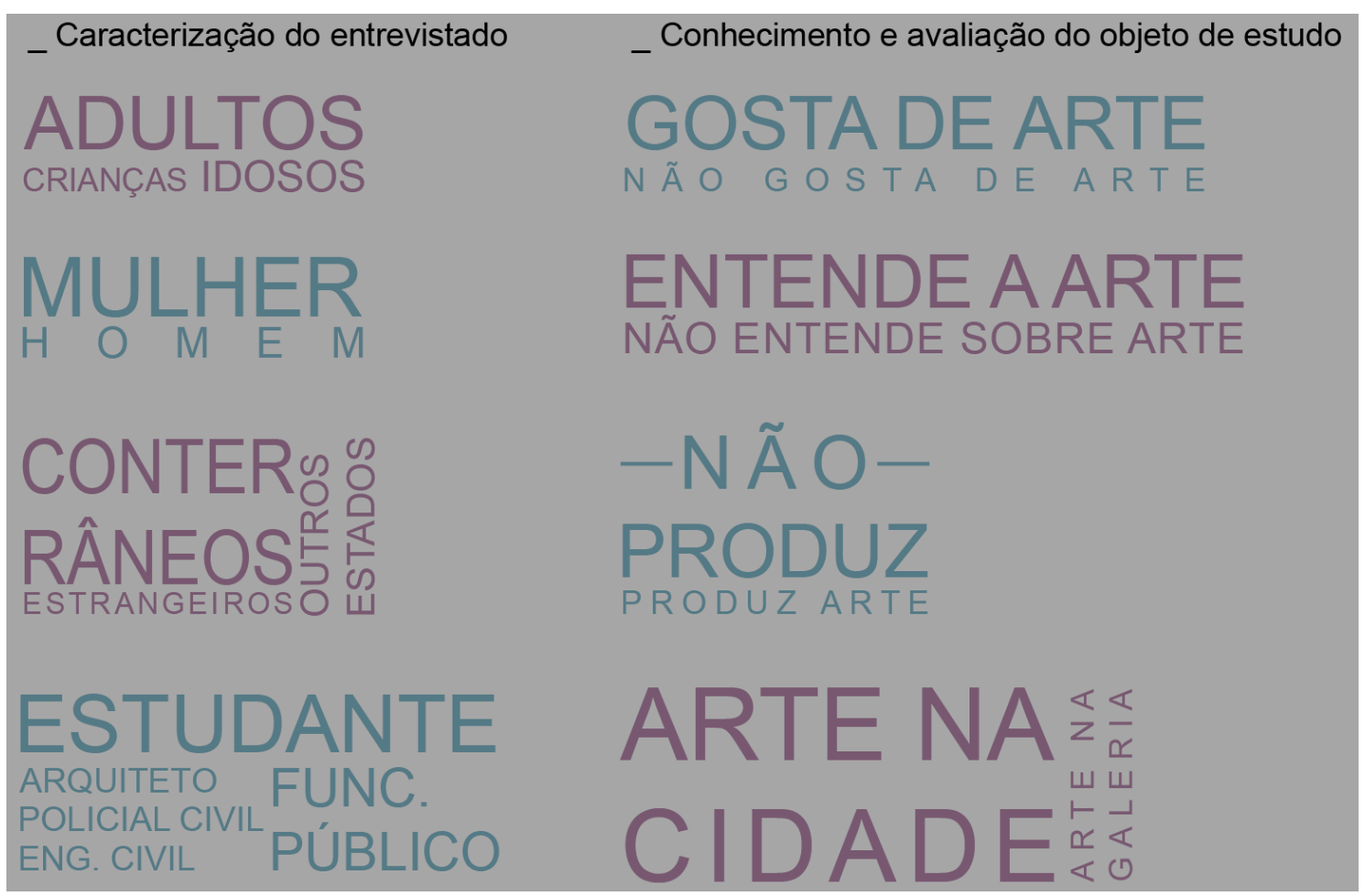

Fonte: elaborado pelas autoras, 2017. 
Figura 9: Resultado gráfico das entrevistas semiestruturadas.

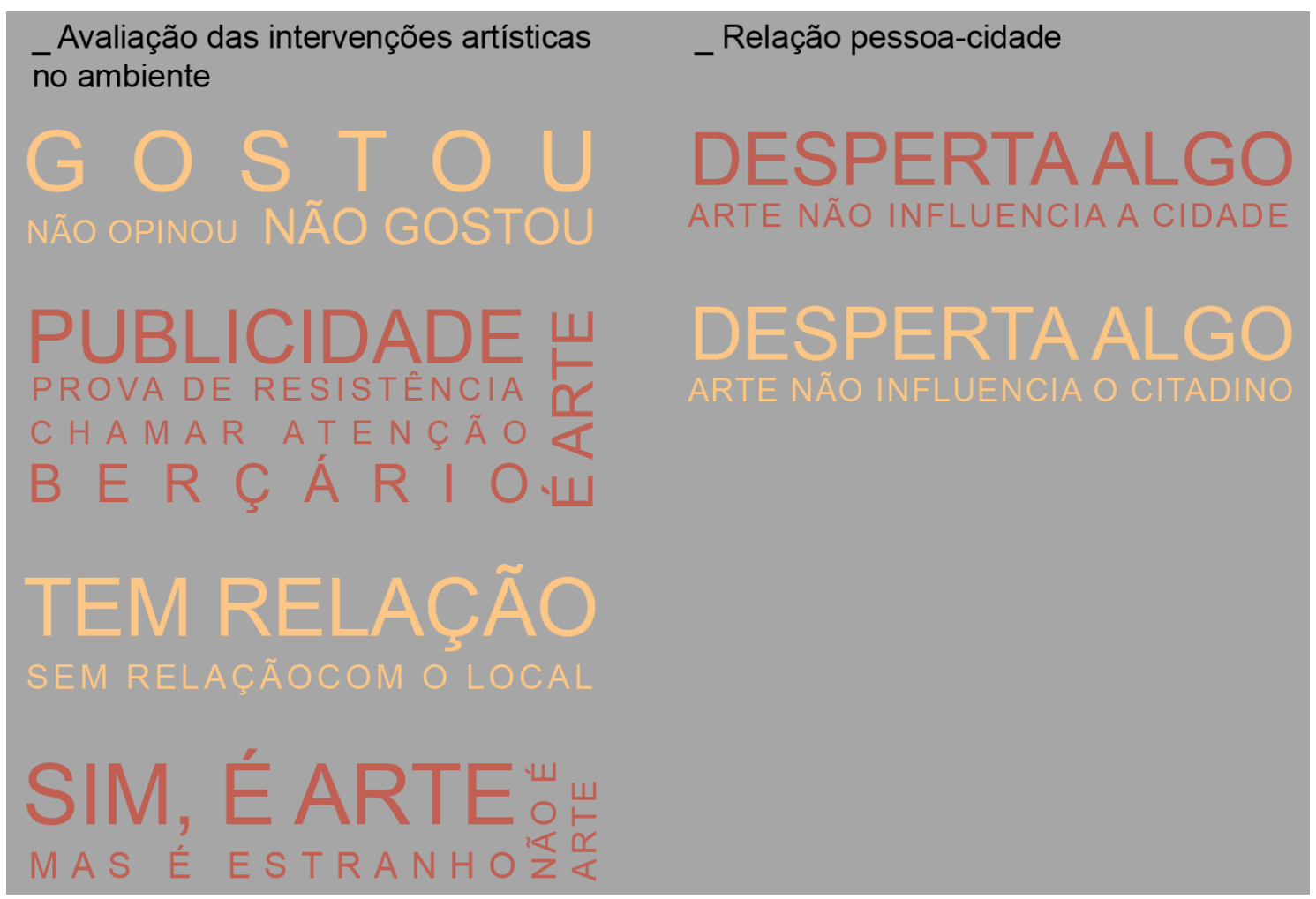

Fonte: elaborado pelas autoras, 2017.

\section{CONSIDERAÇÕES FINAIS}

Os estudos envolvendo arte, arquitetura e urbanismo se relacionam, sobretudo à medida que se compreende que obras artísticas evocam não só o imaginário do artista, mas também sua percepção sobre o contexto social. Ela também se apresenta como forma de protesto, documentação da realidade e propagação de informação entre diversas camadas sociais.

Ao longo do trabalho realizado foi possível perceber que as intervenções provocam reações diversas sobre a relevância delas na cidade e sobre como elas se enquadram no conceito de arte. Isto se relaciona com o que a Arte Contemporânea se propõe a fazer - faz parte de sua essência o questionamento do papel das manifestações artísticas, bem como o lugar onde elas devem estar e os seus significados. Foi notável que a presença dessas artes incita a conexão entre pessoas, e entre pessoas e lugares. Além disto, elas despertam identidade em espaços reféns da homogeneização.

Cartaxo (2009) chama a atenção para que, ao fugir do que foi projetado, estas manifestações artísticas promovem e evidenciam a apropriação de elementos da cidade, condição que as coloca em um contexto onde se confundem com o cotidiano urbano. Ao longo do estudo realizado foi possível entender empiricamente este ponto de vista. Além disto, a pesquisa também corrobora com Fontes (2011) quando explica que os elementos comuns da cidade e do fluxo dos transeuntes são ressignificados a partir da arte, despertando uma diferente relação com o citadino e incitando novas conexões entre a pessoa e o lugar.

$\mathrm{O}$ trabalho realizado possibilitou perceber-se que a presença de arte temporária na cidade quebrou a rotina de Tambaú e Jardim Cidade Universitária, despertando reações diversas nas pessoas, seja de maneira explícita ou sutil. O resultado das entrevistas em Tambaú mostrou que os citadinos, mesmo aqueles que não gostaram da intervenção proposta, são a favor que a arte ocupe lugar na cidade. Por outro lado, as modificações feitas nos lambe-lambes do Jardim Cidade Universitária proporcionaram o entendimento de que nem toda arte poderá ter a recepção esperada, e levanta o questionamento sobre o direito tanto de intervir na cidade quanto de reintervir sobre o que foi proposto.

Todos estes impactos causados, sejam eles positivos ou negativos, fazem parte do legado da arte urbana. As intervenções compõem sua temporariedade visual ou perceptiva, mas deixam marcas, ainda que imateriais, sobre a produção e apropriação do indivíduo na cidade. Aqui, sustenta-se o discurso de Fontes (2011) de que as transformações de um lugar, decorridas de interferências, tornam-no parte da memória 
coletiva e, com isto, o seu legado diz respeito ao abandono da situação de objeto e conquista de configuração como espaço habitado, assim despertando a amabilidade. Ainda, a autora explica que os rastros destas interrupções se constroem sutilmente e fixam com firmeza.

O estudo das relações entre citadinos e intervenções artísticas temporárias permite, portanto, entender-se a dinâmica de apropriação do espaço urbano. À medida que o arquiteto e urbanista entende as práticas sociais existentes tanto no espaço edificado quanto no espaço livre, a probabilidade de criar projetos de sucesso é maior, tendo em vista que o ser humano é seu principal usuário e suas atividades devem ser levadas em consideração. Assim, os estudos da produção da arte urbana também se mostram relevantes para o processo projetual de Arquitetura e Urbanismo, configurando a colaboração e diálogo entre estes diferentes campos.

\section{REFERÊNCIAS}

DIMENSTEIN, M. Experiências Urbanas de Idosos no Centro de João Pessoa. Dissertação de Mestrado. Programa de Pós-graduação em Arquitetura e Urbanismo. João Pessoa: UFPB, 2014.

BAUMAN, Z. Modernidade Líquida. Rio de Janeiro: Zahar. 2001.

BRITTO, F. D.; JACQUES, P. B. Corpocidade: arte enquanto micro-resistência urbana. Fractal: Revista de Psicologia, v. 21, n. 2, p.337-349. Niterói: UFF, maio 2009.

CARTAXO, Z. Ações Performáticas na Cidade: o corpo coletivo. Performance Corpo Coletiva, v. 21, n. 2, p. 1-12 (Periódico do Programa de Pós-Graduação em Artes Cênicas). Rio de Janeiro: UNI-RIO, 2007.

CARTAXO, Z. Arte nos Espaços Públicos: a cidade como realidade. In: O Percevejo Online (Periódico do Programa de Pós-Graduação em Artes Cênicas). Vol. 1, n. 1, p.1-15. Rio de Janeiro: PPGAC/UNRIO, jan./jun. 2009.

DEBORD, G. Sociedade do Espetáculo: Comentários sobre a sociedade do espetáculo. Ebooklibris: Projeto Periferia, 2003.

FERREIRA, M. L.; KOPANAKIS, A. R. A cidade e a Arte: um espaço de manifestação. Revista Tempo da Ciência, v. 22 , n. 44, p.79-88. Toledo: Unioeste, 2005.

FONTES, A. S. Intervenções Temporárias, Marcas Permanentes: a amabilidade nos espaços coletivos de nossas cidades. 2011. Tese (Doutorado). Programa de Pós-Graduação em Urbanismo, UFRJ. Rio de Janeiro, 2011.

GEHL, J. Cidade Para Pessoas. São Paulo: Editora Perspectiva, 2015.

GERHARDT, T. E.; SILVEIRA, D. T. (Org.). Métodos de Pesquisa. Porto Alegre: Editora UFRGS, 2009.

GOMBRICH, E. H. A História da Arte. Rio de Janeiro: Ltc, 2000.

IMBROISI, M.; MARTINS, S. História das Artes. 1998. Disponível em: <http://www.historiadasartes.com/>. Acesso em: 14 abr. 2017.

JACQUES, P. B. Errâncias urbanas: a arte de andar pela cidade. Arqtexto, v. 7, p.16-25. Rio Grande do Sul: UFRGS, 2005.

MELO, J. C. S. A cidade grita: Intervenções artísticas temporárias em João Pessoa. Trabalho de Conclusão de Curso. (Graduação em Arquitetura e Urbanismo), Centro Universitário de João Pessoa. João Pessoa, PB, 2017.

MENDES, E. B. Cidades instáveis: intervenção artística como experiência heterotópica do espaço urbano. O Percevejo Online (Periódico do Programa de Pós-Graduação em Artes Cênicas), vol. 4, n. 2, p.1-19. Rio de Janeiro: PPGAC/UNIRIO, 2012.

NASCIMENTO, J. P. C. A condição pós-moderna, de Jean-François Lyotard. In: NASCIMENTO, J. P. C. Abordagens do pós-moderno em música: a incredulidade nas metanarrativas e o saber musical contemporâneo. São Paulo: UNESP, 2011.

NOGUEIRA, C. A (im)permanência do traço: rastro, memória e contestação. In: PRACS (Revista Eletrônica de Humanidades do Curso de Ciências Sociais da UNIFAP), vol 2, n. 2. Macapá: UNIFAP, 2009.

OXFORD, University Of. Dicionário Oxford Escolar: para estudantes brasileiros de inglês. Oxford: Oxford University Press, 2005.

PALLAMIN, V. M. Arte urbana como prática crítica. In: PALLAMIN, V. M. (Org). Cidade e Cultura: esfera pública e transformação urbana. São Paulo: Estação Liberdade, 2002.

PALLAMIN, V. M. Arte Urbana: São Paulo: região central (1945 - 1999). São Paulo: Annablume Editora, 2000.

PEIXOTO, N. B. Intervenções urbanas. In: PEIXOTO, N. B. (Org). Intervenções Urbanas: arte/cidade. São Paulo: SENAC-São Paulo, 2012.

ZEVI, B. Saber Ver Arquitetura. São Paulo: Editora WMF / Martins Fontes, 2009. 


\section{NOTAS}

${ }^{1}$ Esta categoria foi elaborada para esta pesquisa a partir da constatação empírica da tentativa de apagar algumas obras de grafite encontradas, provavelmente por parte de donos dos imóveis.

${ }^{2}$ Ferramenta para organizar conteúdos em redes sociais, reunindo assuntos de um mesmo tópico e precedido pelo símbolo \#.

${ }^{3}$ No livro Temporary Urban Spaces: Concepts for the Use of City Spaces (2006).

${ }^{4}$ Esse foi o entendimento adotado no TCC (MELO, 2017). Entretanto, em estudos posteriores à sua finalização, foi entendido que o tópico de grafite e pichação é bastante abrangente e com controvérsias sobre as nomenclaturas, significados e artistas produtores, gerando quase uma dicotomia e dificultando a redução dos dois conceitos em um só. Além disto, também foi posteriormente compreendido que as denominações pichação e pixo têm pesos diferentes em suas definições.

${ }^{5}$ BRASIL. Lei no 12.408 , de 25 de maio de 2011.

${ }^{6}$ Durante palestra no Instituto de Educação Superior da Paraíba (IESP).

NOTA DO EDITOR $\left(^{*}\right)$ O conteúdo do artigo e as imagens nele publicadas são de responsabilidade do(s) autor(es). 